\title{
Changes of soil microbial characteristics in saline-sodic soils under drip irrigation
}

\author{
S.H. Liu ${ }^{1}$, Y.H. Kang ${ }^{2 *}$ \\ ${ }^{1}$ College of Water Resource Science and Engineering, Taiyuan University of Technology, Taiyuan 030024, China. ${ }^{2}$ Key Laboratory \\ of Water Cycle and Related Land Surface Processes, Institute of Geographic Science and Natural Resources Research, Chinese \\ Academy of Sciences, Anwai, Beijing 100101, China. *Corresponding author: kanghy@igsnrr.ac.cn
}

\begin{abstract}
A field experiment was carried out to study the changes of soil bacteria, fungi and actinomycetes in saline-sodic soils for different numbers of cultivated years under drip irrigation. The drip irrigation had substantial effects on levels of bacteria, fungi and actinomycetes. With increased number of cultivated years under drip irrigation, the soil biological properties were greatly improved. After three years of cultivation, the respective increases in the levels of bacteria, fungi and actinomycetes were 103.7, 72.7 and 58.2 times those of uncultivated land. In the vertical direction, the colony forming units of bacteria, fungi and actinomycetes all decreased with increased soil depth. We forecast that the soil microbial characteristics in drip-irrigated saline-sodic soils should match those of natural Leymus chinensis grassland after 6-7 years of cultivation.
\end{abstract}

Keywords: Leymus chinensis, restoration, saline-sodic grassland, soil microbial characteristics

\section{Introduction}

Soil microbes are a key component in soil ecosystems, dominating the cycling of nutrient elements and playing a major role in maintaining soil quality (Wang et al., 2008). Microorganisms respond rapidly to changes in their environment (Stefanowicz, 2006; Zhang and $\mathrm{Xu}, 2008$; Jiang et al., 2012) and following disturbance, changes in soil conditions are expected to affect the activity, structure and function of microbial communities (Bååth et al., 1995; Papatheodorou et al., 2004). Because of their sensitivity, biological properties of soil have often been proposed as early and sensitive indicators of soil ecological stress or other environmental changes (Dick, 1994; Oliveira and Pampulha, 2006; Li et al., 2011). Soil microbial characteristics are important indexes for evaluating soil quality.

The Songnen Plain covers an area of about $17.0 \times$ $10^{6} \mathrm{ha}$, and is one of the five largest salt-affected soil regions in China (Yu and Cheng, 1991; Chi and Wang, 2010). The climate is classified as lying at the transition between sub-humid and semi-arid conditions, leaving the possibility of its use for agriculture as well as grazing. In the past it was good pasture and had many fine grasses, with grasslands dominated by Leymus chinensis (Xiao et al., 1995; 
Liu and Han, 2008; Wang et al., 2009). However, in recent decades, the vast grasslands on the Songnen Plain have suffered from degradation due to soil alkalization induced by overgrazing (Gao et al., 1996). Salinization and alkalization have substantially changed the properties of soil in the Songnen Plain. The saline-sodic soils are characterized by a high $\mathrm{pH}$ and a large exchangeable sodium percentage (ESP) (Wang et al., 2004; Chi and Wang, 2010). The soil is very poor, and the decreased soil microbial characteristics pose a very serious problem.

With increasing attention paid to the environment in recent years, many measures have been taken to restore degraded grasslands to their original states. Many studies have shown that drip irrigation is an important method for improving saline land (Wan et al., 2007; Chen et al., 2009; Kang et al., 2010). Tan and Kang (2009) found that the physical, chemical and microbial properties of saline soil were greatly improved after three years of drip irrigation. Liu et al. (2011) used drip irrigation of transplanted L. chinensis for restoration of saline-sodic soils, and found that salt was effectively leached from the soil and reported good growth of L. chinensis. However, changes in soil microbial characteristics during reclamation of salinesodic grassland have not been well clarified.

Inspired by these studies, our research examined the changes in soil microbial characteristics under drip irrigation. The objectives of this study were to (1) investigate the spatial distribution of bacteria, fungi and actinomycetes in the soil profile under drip irrigation and (2) show the restoration effects of soil microbial characteristics on saline-sodic grassland under drip irrigation after three years, using natural $L$. chinensis grassland as a reference.

\section{Materials and Methods}

\subsection{Experiment site}

The research area is located in $45^{\circ} 35^{\prime} 58^{\prime \prime}-45^{\circ} 36^{\prime} 28^{\prime \prime} \mathrm{N}$ and $123^{\circ} 50^{\prime} 27^{\prime \prime}-123^{\circ} 51^{\prime} 31 \mathrm{E}$ in the western part of the Songnen Plain, northeast China, with elevation of $110-140 \mathrm{~m}$. The climate of the area is a combination of temperate, semi-humid and semi-arid monsoon. The freezing period is from early November to late May of the following year. The annual average temperature is $3-5{ }^{\circ} \mathrm{C}$, and the lowest monthly average temperature is -15 to $-18^{\circ} \mathrm{C}$ in January. Annual average precipitation is $414 \mathrm{~mm}$, of which $70-80 \%$ falls during JulySeptember. Annual evaporation in this region is 1792 $\mathrm{mm}$. Seasonal drought occurs frequently in spring and autumn, and $90 \%$ of springs experience drought. Seasonal changes in the groundwater level cause salts to accumulate in the soil profile. The groundwater depth is about $2 \mathrm{~m}$, and irrigation mainly depends on groundwater. The soil physical and chemical properties are shown in Table 1.

\subsection{Experimental design}

Field experiments were conducted in 2008-2010 during the growth period of L. chinensis (early May to late September). Fields were planted with L. chinensis and cultivated for one-, two- or threeyear periods. Natural L. chinensis grassland adjacent to the experimental site was used as a reference for all comparisons. The experiment field was divided into three plots (each $4.8 \mathrm{~m} \times 4 \mathrm{~m}$ ) to provide three replicates. All plots were planted with $L$. chinensis and supplied with drip irrigation. The soil matric potential (SMP) directly beneath the $20-\mathrm{cm}$ depth emitters was maintained at $-10 \mathrm{kPa}$. The tensiometers were observed three times daily (at 07:00, 14:00 and 18:00 h) and drip irrigation was performed if tensiometer readings dropped below $-10 \mathrm{kPa}$. The amount of the first irrigation in the three plots was about $21 \mathrm{~mm}$ in order to leach salts in the upper layer of soil. Thereafter, the tensiometer was used to trigger irrigation, and $3.5 \mathrm{~mm}$ water was applied at early growth stages and $7 \mathrm{~mm}$ at later stages. On the undisturbed salt-affected land, the colony forming units (CFU) of bacteria, fungi and actinomycetes were very low, at $0.8 \times 10^{4}, 0.32 \times 10^{2}$ and $2.8 \times 10^{4}$ CFU g ${ }^{-1}$ dry soil before cultivation, respectively. 
Table 1. Physical and chemical properties of tested soil

\begin{tabular}{cccccccc}
\hline $\begin{array}{c}\text { Soil } \\
\text { layers } \\
(\mathrm{cm})\end{array}$ & $\mathrm{pH}$ & $\begin{array}{c}\mathrm{EC}_{\mathrm{e}} \\
\left(\mathrm{dS} \mathrm{m}^{-1}\right)\end{array}$ & $\begin{array}{c}\text { Total } \\
\text { salt } \\
\left(\mathrm{g} \mathrm{kg}^{-1}\right)\end{array}$ & $\begin{array}{c}\text { Total } \\
\text { nitrogen } \\
\left(\mathrm{g} \mathrm{kg}^{-1}\right)\end{array}$ & $\begin{array}{c}\text { Total } \\
\text { phosphorus } \\
\left(\mathrm{g} \mathrm{kg}^{-1}\right)\end{array}$ & $\begin{array}{c}\text { Total } \\
\text { potassium } \\
\left(\mathrm{g} \mathrm{kg}^{-1}\right)\end{array}$ & $\begin{array}{c}\text { Organic } \\
\text { carbon } \\
\left(\mathrm{g} \mathrm{kg}^{-1}\right)\end{array}$ \\
\hline $0-10$ & 9.79 & 15.25 & 4.17 & 0.50 & 0.10 & 34.80 & 6.10 \\
$10-20$ & 9.77 & 13.56 & 3.83 & 0.60 & 0.11 & 33.80 & 7.80 \\
$20-30$ & 9.82 & 13.2 & 5.83 & 0.60 & 0.11 & 32.30 & 7.90 \\
$30-40$ & 9.88 & 12.02 & 7.5 & 0.40 & 0.10 & 30.10 & 7.40 \\
\hline
\end{tabular}

Soil samples were measured by the saturated-soil extract, water samples were obtained using a centrifuge, and the water extract was measured for total dissolved solids, ECe and $\mathrm{pH}$

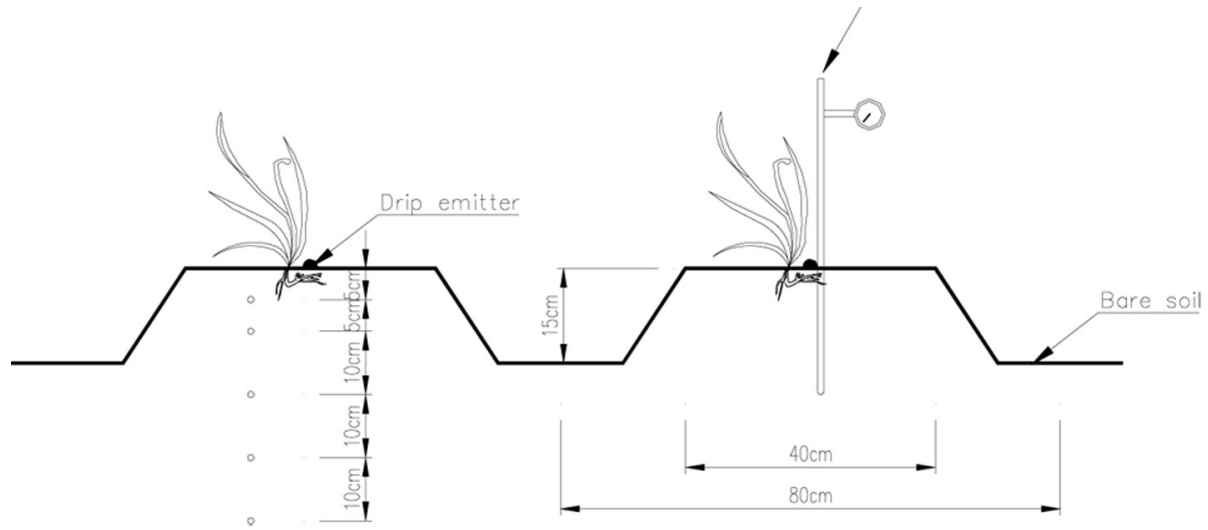

Figure1. Layout of the position of the tensiometer and soil samples

\subsection{Agronomic practices}

All experimental fields were raised beds that had been ploughed to about $25 \mathrm{~cm}$ depth using a rotary tiller pulled with a tractor. Each plot contained six raised beds (15 $\mathrm{cm}$ in height). The widths and lengths of the beds were 0.8 and $4.0 \mathrm{~m}$, respectively (Figure 1). Drip tubes were placed in the center of each bed with emitters spaced $0.2 \mathrm{~m}$ apart. The drip tubes were $4 \mathrm{~m}$ long, and the distance between any two drip tubes was $0.8 \mathrm{~m}$. The $L$. chinensis plants were transplanted from a wild $L$. chinensis community local to the experimental land in mid-July 2008. The L. chinensis plants were planted in single rows on each bed, with $0.8 \mathrm{~m}$ between rows and $0.4 \mathrm{~m}$ between plants. The experimental land was equipped with an independent gravity-type irrigation system. . The irrigation system consisted of a plastic barrel $(400 \mathrm{~L})$ used as a water source, 18 drip tubes (six tubes per plot), a ball valve installed under the bottom of the barrel to control irrigation and an outlet $1.2 \mathrm{~m}$ above the ground surface. Before each irrigation, $40 \mathrm{~g}$ of urea, $10 \mathrm{~g}$ of phosphoric acid and $16 \mathrm{~g}$ of potassium dihydrogen phosphate were added into the barrel so that fertilizer was applied with the 
irrigation water. Specifically, nitrogen $(\mathrm{N})$, phosphorus $(\mathrm{P})$ and potassium $(\mathrm{K})$ were provided in proportions of 4:1:1. During the growth stage of $L$. chinensis, urea, phosphoric acid and potassium dihydrogen phosphate were applied as top dressing as follows: in 2008 with 42,10 and $17 \mathrm{~kg} \mathrm{ha}^{-1}$, respectively; the corresponding levels in 2009 were 123, 31 and $49 \mathrm{~kg} \mathrm{ha}^{-1}$; and in 2010 were 188,47 and $75 \mathrm{~kg} \mathrm{ha}^{-1}$.

\subsection{Soil sampling and analysis}

During 2008-2010, at the middle of the growth period of $L$. chinensis, soil samples were obtained from each plot using an auger $(2.0 \mathrm{~cm}$ in diameter and $15 \mathrm{~cm}$ in height). Samples were collected on 30 May 2008, 30 July 2008, 20 July 2009 and 25 July 2010. The depths were $0-5,5-10,10-20,20-30$ and $30-40 \mathrm{~cm}$ on the experimental land (Figure 1). Soil samples in $0-5,5-10,10-20,20-30$ and $30-40 \mathrm{~cm}$ layers on the natural $L$. chinensis grassland were taken at the same time. The soil samples were for analysis of electrical conductivity of saturated-soil extract (ECe), $\mathrm{pH}$, soil enzyme activities and available $\mathrm{P}, \mathrm{K}$ and $\mathrm{N}$. They were air-dried and sieved through a 2-mm sieve, and ECe determined using a conductivity meter (DDS-11A, REX, Shanghai) and $\mathrm{pH}$ determined by $\mathrm{pH}$ meter (PHS-3C, REX, Shanghai). Saturated paste (SP) extracts was determined according to guidelines in the USDA Handbook 60 (USDA, 1954). Available $\mathrm{P}$ was measured by molybdenum-antimony antispectrophotometric method, available $\mathrm{K}$ by flame photometer and available $\mathrm{N}$ by spectrophotometer (Bao, 2000). Alkaline phosphatase, urease and sucrase activities were measured spectrophotometrically. Alkaline phosphatase activities were determined by disodium phenyl phosphate method, urease activities colorimetrically by the indophenol blue method and sucrase activities by the 3,5-dinitrosalicylic acid method (Guan, 1986). Other soil samples were stored in a refrigerator at $4{ }^{\circ} \mathrm{C}$ until the microorganisms count experiment was completed. The CFU of soil microorganisms were determined by dilution plate counts. Bacteria were cultured in beef-protein medium, fungi in Czapek's medium and actinomycetes in Gaoshi 1 medium (Yang and Xiao, 2003).

\subsection{Statistical analysis}

All average quantities of bacteria, fungi and actinomycetes were calculated by the weighted mean method, e.g. average quantities of bacteria (BAC) for root zone at planting year i [BAC(i)] was calculated from $\mathrm{BAC}(\mathrm{j}, \mathrm{k})$ and $\mathrm{S}(\mathrm{j}, \mathrm{k})$ data $(\mathrm{j}=0,8,16,24,32,40$; $\mathrm{k}=2.5,7.5,15,25,35)$ :

$$
B A C(i)=\sum_{\substack{j=0,8,16,24,32,40 \\ k=2.5,7.5,15,25,35}} B A C(i, j, k) \times S(j, k) / \sum_{\substack{j=0,8,16,24,32,40 \\ k=2.5,7.5,15,25,35}} S(j, k)
$$

$\mathrm{BAC}(\mathrm{i}, \mathrm{j}, \mathrm{k})$ is the BAC quantity of the soil sample in soils planted for $\mathrm{i}$ years, in which $\mathrm{j}$ is the horizontal distance to drip line and $\mathrm{k}$ is the average depth to soil surface. $S(j, k)$ is the representative area of the soil sample. Quantities of fungi and actinomycetes were all calculated by the same method.

\section{Results}

3.1. Distribution of soil enzyme activities for different periods of cultivation
Using drip irrigation on transplanted L. chinensis plots for three years greatly increased the alkaline phosphatase, urease and sucrase activities compared to land without drip irrigation.

The distribution of alkaline phosphatase activity is shown in Figure 2a. In the horizontal direction, for irrigated land the alkaline phosphatase activity was always higher near the emitter than further away. After drip irrigation for two years, the alkaline phosphatase 
activity near the emitter was 2.24 times that on the land before irrigation, and this increased to five times after three years of irrigation. The alkaline phosphatase activities under the emitter, and $8 \mathrm{~cm}$ away were higherthan at 16, 24, 32 and $40 \mathrm{~cm}$ away, in the one-, two- and three-year irrigated land. In the vertical direction, the alkaline phosphatase activity decreased with increased soil depth for all treatments, including the land before drip irrigation and that with one, two and three years of drip irrigation. The upper layer had good water and nutrient conditions, and there were clear differences in alkaline phosphatase activity in the surface layers after the different periods of irrigation.

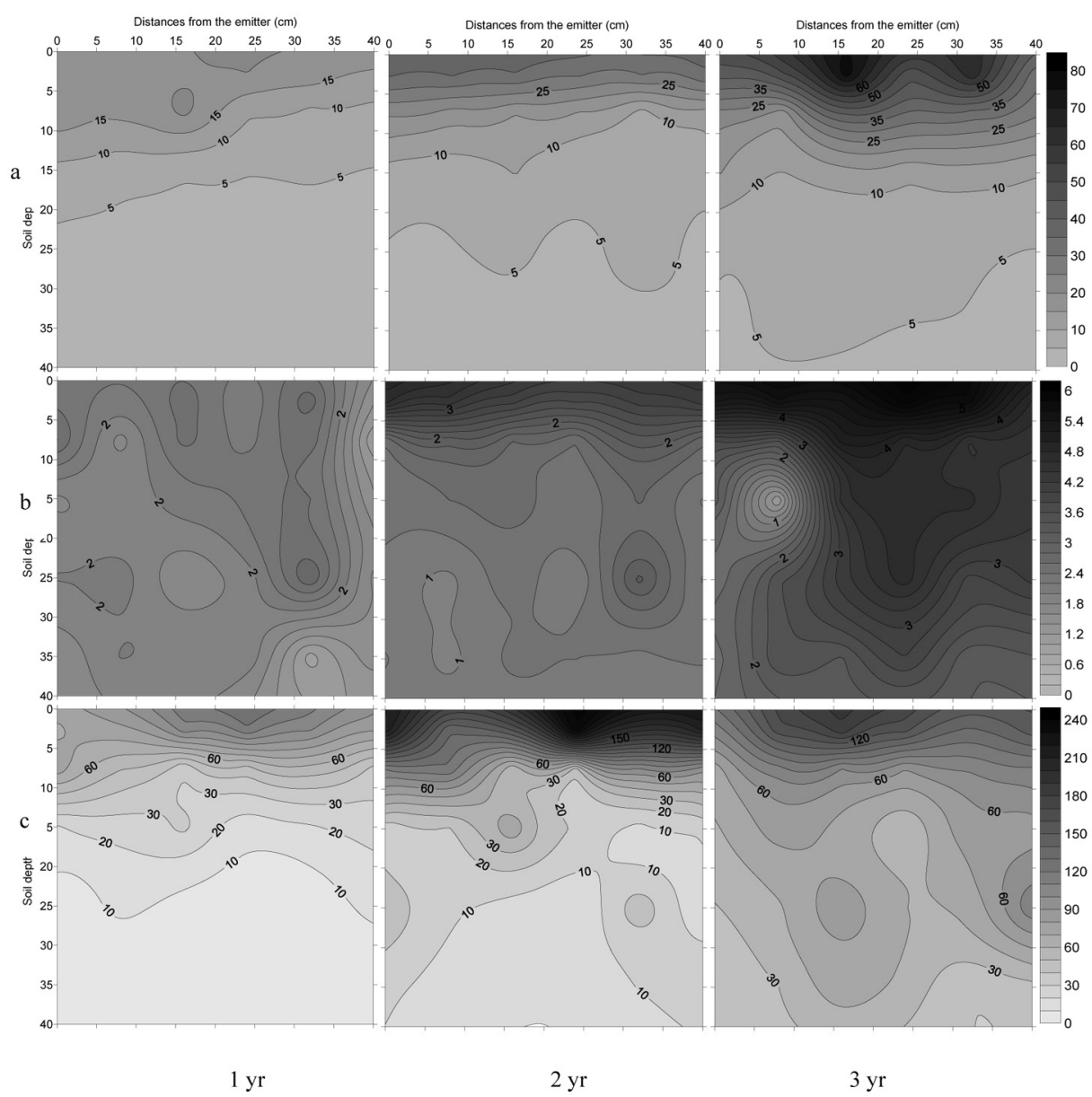

Figure 2. Distribution of soil enzyme activities for different planting years 
The distribution of urease activities is shown in Figure $2 b$. There was no clear change in urease activities in the horizontal direction for both the one- and two-year irrigated land. After drip irrigation for three years, urease activity near the emitter was greatly improved, but decreased with increased distance from the emitter. Urease activity under the emitter was 1.6 times that at $40 \mathrm{~cm}$ away from the emitter. Urease activity in the surface layer was higher than in deeper soil, similarly to alkaline phosphatase activity.

The sucrase activity on the one-year drip irrigation land did not clearly change in a horizontal direction. However, for the two-year irrigated land, sucrase activity under the emitter was higher than at 8,16 , 24,32 and $40 \mathrm{~cm}$ away. Sucrase activity was greatly increased for the three-year irrigated land. The vertical distribution of sucrase activity for different periods of irrigation was similar to that for urease activity - it decreased with increased soil depth and increased with number of years of irrigation. The sucrase activity in 0-20-cm soil layers increased quickly with cultivated years; however, there were no clear differences in the $30-40-\mathrm{cm}$ layers for one and two years of irrigation, but for three-year irrigated land, sucrase activity was much higher than for the previous years (Figure 2c).

\subsection{Distribution of bacteria, fungi and actinomycetes with period of cultivation}

The CFU of bacteria increased with the duration of drip irrigation. The CFU of bacteria in $0-40-\mathrm{cm}$ soil layers on the uncultivated salt-affected land was low. After cultivation, this significantly increased in the $0-40-\mathrm{cm}$ soil layers (Figure 3a). Compared with uncultivated salt-affected land, the average CFU of bacteria in 0-40-cm soil layers increased by 17, 102 and 193 times on the one-, two- and three-year irrigated land, respectively. After two years of drip irrigation, the $\mathrm{CFU}$ of bacteria had increased further, and reached more than $150 \times 10^{4} \mathrm{CFU} \mathrm{g}^{-1}$ dry soil in the $0-10-\mathrm{cm}$ soil layers, and the CFU of bacteria increased with three years of irrigation. This indicated that cultivation had improved the soil environment and it was more favorable for bacterial growth. In the vertical direction, the CFU of bacteria in the surface soil layers were higher than the subsoil on uncultivated and one-, twoand three-year irrigated land. On the uncultivated land, there were no bacteria in the $20-40-\mathrm{cm}$ soil layers. After one year of irrigation, the CFU of bacteria increased in the $0-20-\mathrm{cm}$ soil layers, but in the 20-40$\mathrm{cm}$ soil layer it was very low.

The CFU of fungi also increased over the course of drip irrigation. On uncultivated land, the CFU of fungi was very low. After cultivation, this significantly increased in the $0-40-\mathrm{cm}$ soil layers (Figure 3b). Compared with uncultivated salt-affected land, the average CFU of fungi in $0-40-\mathrm{cm}$ layers increased by 6, 59 and 153 times on the one-, two- and threeyear irrigated land, respectively. After two years of drip irrigation, the CFU of fungi had increased further, especially in the $0-5-\mathrm{cm}$ soil layers, where it reached more than $72 \times 10^{2} \mathrm{CFU} \mathrm{g}^{-1}$ dry soil. Over the three years of drip irrigation, the $\mathrm{CFU}$ of fungi had increased continuously, and the increasing degree was apparent, the CFU of fungi in the $0-5-\mathrm{cm}$ soil layers was $1.14 \times$ $10^{4} \mathrm{CFU} \mathrm{g}^{-1}$ dry soil. In the vertical direction, the CFU of fungi was higher in the surface soil layers than in subsoil on the uncultivated and one-, two- and threeyear irrigated land.

The CFU of actinomycetes in $0-40-\mathrm{cm}$ soil layers on land before irrigation was low. Levels of actinomycetes in 0-40-cm soil layers increased over the course of the experiment. Compared with salt-affected land before irrigation, the average CFU of actinomycetes in 0-40$\mathrm{cm}$ soil layers increased by 8,59 and 83 times on the one-, two- and three-year irrigated land, respectively. In the vertical direction, the CFU of actinomycetes decreased with increased soil depth for land irrigated for one, two and three years (Figure 3c). After one year of fertilization and drip irrigation, changes in CFU of actinomycetes were slight compared to uncultivated land. However, the $\mathrm{CFU}$ of actinomycetes were increased greatly after the second and third years. On cultivated land after three years, there was a substantial increase in CFU of actinomycetes in the $0-10$-cm layer. 


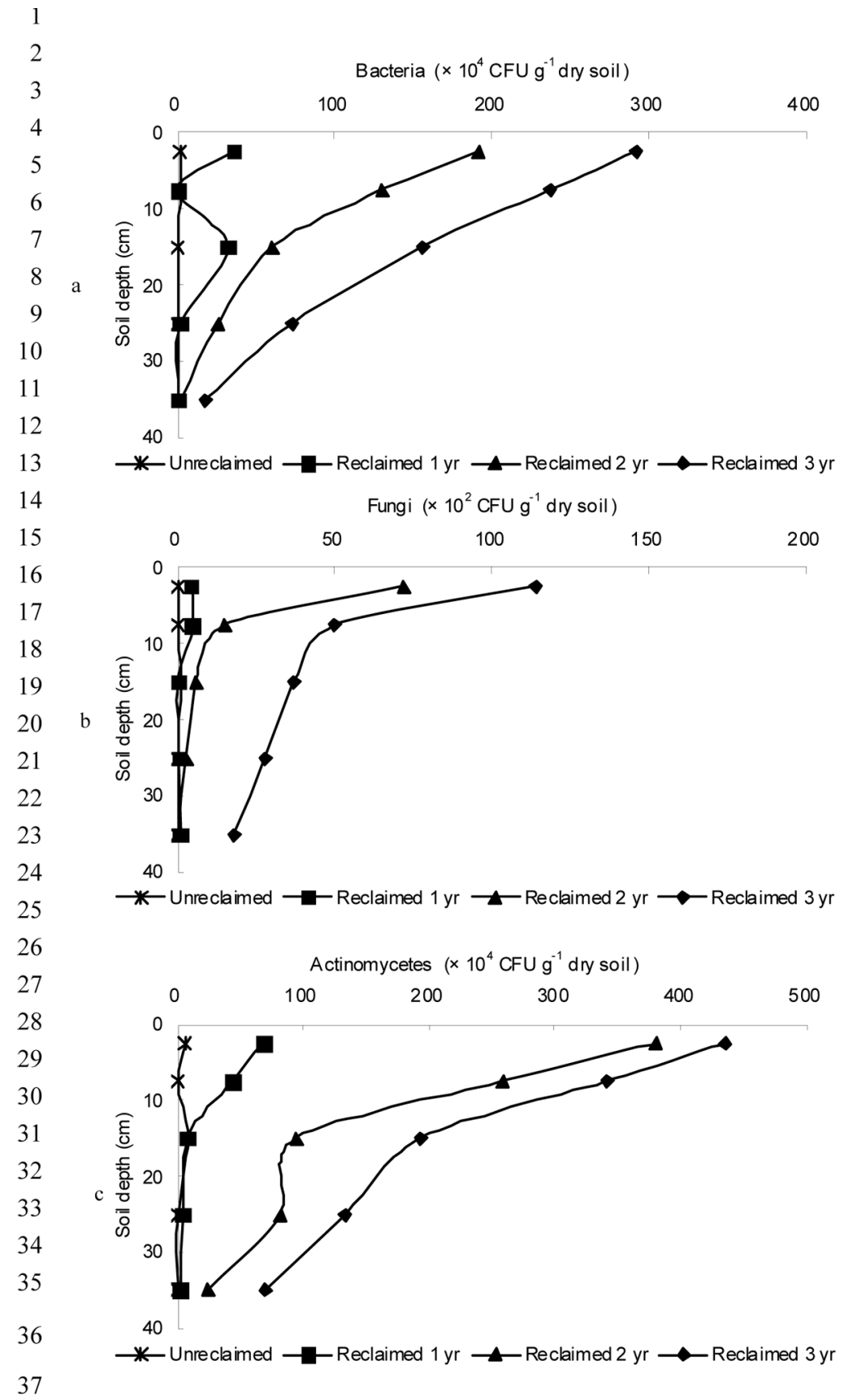

Figure 3. Distribution of bacteria, fungi, and actinomycetes for different planting years 


\subsection{Correlations between soil microorganisms and soil environmental factors}

After three years of irrigation, the growing conditions of L. chinensis changed as the soil environment greatly improved. The soil salinity and $\mathrm{pH}$ in the root layers decreased significantly, the average ECe in $0-40-\mathrm{cm}$ soil layers was $4.87 \mathrm{dS} \mathrm{m}^{-1}$, total salt was $2.92 \mathrm{~g} \mathrm{~kg}^{-1}$ and average $\mathrm{pH}$ was 9.48 . Soil fertility was enhanced greatly. The average total $\mathrm{N}$, total $\mathrm{P}$, total $\mathrm{K}$ and organic carbon (C) in $0-40-\mathrm{cm}$ soil layers increased to 0.68 , $0.3,41.2$ and $8.87 \mathrm{~g} \mathrm{~kg}^{-1}$.

The alkaline phosphatase, urease and sucrase activities for soil enzyme activities; ECe and $\mathrm{pH}$ for soil chemical properties; and available $\mathrm{P}, \mathrm{K}, \mathrm{N}$ and organic $\mathrm{C}$ for soil nutrients, were used to investigate correlations with soil microbial characteristics (Table 2 ). The soil was very poor and microbial activity low in the land before drip irrigation and after one year of irrigation - the correlations of microbial activities and soil physical and chemical properties were very low. After irrigation for two years, the soil environment was improved greatly, and there were significant positive correlations between bacteria, fungi and actinomycetes and phosphatase, urease and sucrase activities; and significant negative correlations with $\mathrm{ECe}$ and $\mathrm{pH}$. The same pattern appeared in land irrigated for three years.

\subsection{Restoration of saline-sodic grassland under drip irrigation}

Three years of fertilization and drip irrigation considerably improved the soil microbial characteristics. Levels of the soil microbial characteristics of natural grasslands were much higher than for the land before the experiment (Table 3). The $\mathrm{CFU}$ of bacteria on the land before irrigation were only $0.3 \%$ that of the natural grassland. This ratio increased to $4.9,28.9$ and $54.6 \%$ after one, two and three years of drip irrigation, respectively. The CFU of fungi on uncultivated land was only $0.5 \%$ of that for natural grassland, and improved to $3.4,30.1$ and $77.7 \%$ by the end of the first, second and third years of irrigation, respectively. The actinomycete content on uncultivated land was only $0.63 \%$ of that for natural grassland, and improved to $5.6,37.4$ and $52.4 \%$ by the end of the first, second and third years, respectively.

Regression analysis showed that the relationships between bacteria, fungi and actinomycetes and the planting year could be expressed as:

$$
\begin{array}{ll}
B A_{f}=14.161 x^{2}-17.351 x & R^{2}=0.99 \\
F U_{f}=7.1 x^{2}-19.076 x+12.2 & R^{2}=0.99 \\
A C_{f}=11.1 x^{2}+28.22 x-46.3 & R^{2}=0.95
\end{array}
$$

Where $B A_{f}, F U_{\mathrm{f}}$ and $A C_{\mathrm{f}}$ are the average bacteria, fungi and actinomycete counts, respectively; and $x$ is the planting year, $x \in\{0,1,2,3\}$

If they continued to increase at this rate, the bacteria, fungi and actinomycete counts would reach the level of natural grassland in 6-7 years.

\section{Discussion}

Cultivation of transplanted L. chinensis on salinesodic grassland under drip irrigation improved the levels of soil microbial characteristics, with substantial enhancement of soil microbial characteristics after three years. After three years of irrigation, the respective increases in levels of bacteria, fungi and actinomycetes were 103.7, 58.2 and 72.7 times that of the land before irrigation The results were identical to Tan and Kang (2010), who reported that soil microbial characteristics steadily increased in saltaffected land following irrigation. With the increase in cultivated years, the soil microbial characteristics rapidly increased, indicating an improved soil environment. The results were similar to $\mathrm{Hu}$ et al. (2007), who found that planting Achnatherum splendens (Trin) Nevski improved alkali soil; and the total quantity of bacteria and actinomycetes increased with increased time of cultivation. 
Table 2. The coefficients between soil microorganism and the soil environment factors of different planting years.

\begin{tabular}{|c|c|c|c|c|c|c|c|c|c|}
\hline Treatments & $\begin{array}{c}\text { Soil } \\
\text { microorganism }\end{array}$ & AKP & Ur & Inv & $\mathrm{ECe}$ & $\mathrm{pH}$ & $\begin{array}{c}\text { Available } \\
\text { Phosphorus }\end{array}$ & $\begin{array}{l}\text { Available } \\
\text { Potassium }\end{array}$ & $\begin{array}{l}\text { Available } \\
\text { Nitrogen }\end{array}$ \\
\hline \multirow{3}{*}{ Unreclaimed } & BAC & $0.520 * *$ & $-0.549 * *$ & $0.697 * *$ & 0.357 & -0.284 & 0.017 & -0.040 & 0.189 \\
\hline & FUN & -0.244 & -0.190 & -0.020 & 0.190 & $-0.470 * *$ & -0.232 & $-0.559 * *$ & -0.213 \\
\hline & ACT & 0.330 & $-0.616^{* *}$ & $0.446^{*}$ & $0.458 * *$ & -0.194 & 0.324 & $0.594 * *$ & 0.359 \\
\hline \multirow{3}{*}{$\begin{array}{l}\text { Reclaimed } \\
1 \mathrm{yr}\end{array}$} & BAC & $0.379 *$ & $0.469 * *$ & $0.577^{* * *}$ & 0.126 & -0.232 & 0.145 & $0.459^{*}$ & 0.129 \\
\hline & FUN & $0.746 * *$ & $0.390 *$ & $0.593 * *$ & -0.095 & -0.213 & 0.314 & 0.357 & 0.138 \\
\hline & $\mathrm{ACT}$ & $0.886^{* *}$ & $0.662 * *$ & $0.804 * *$ & -0.017 & -0.284 & 0.240 & $0.445^{*}$ & 0.189 \\
\hline \multirow{3}{*}{$\begin{array}{l}\text { Reclaimed } \\
2 \mathrm{yr}\end{array}$} & BAC & $0.847 * *$ & $0.581 * *$ & $0.799 * *$ & $-0.669 * *$ & $-0.461^{*}$ & $0.757^{* *}$ & $0.631^{* *}$ & $0.875^{* *}$ \\
\hline & FUN & $0.920 * *$ & $0.630^{* *}$ & $0.886 * *$ & $-0.617 * *$ & $-0.528 * *$ & $0.443^{*}$ & $0.786^{* *}$ & $0.835^{* *}$ \\
\hline & $\mathrm{ACT}$ & $0.908 * *$ & $0.567^{* *}$ & $0.859 * *$ & $-0.641 * *$ & $-0.447^{*}$ & $0.658 * *$ & $0.623 * *$ & $0.796^{* *}$ \\
\hline \multirow{3}{*}{$\begin{array}{l}\text { Reclaimed } \\
3 \mathrm{yr}\end{array}$} & BAC & $0.752 * *$ & $0.538^{* *}$ & $0.645^{* *}$ & $-0.803 * *$ & $-0.766^{* *}$ & $0.813^{* *}$ & -0.086 & $0.876^{* *}$ \\
\hline & FUN & $0.731^{* *}$ & $0.563 * *$ & $0.651^{* *}$ & $-0.589 * *$ & $0.615^{* *}$ & $0.759 * *$ & -0.187 & $0.855^{* *}$ \\
\hline & $\mathrm{ACT}$ & $0.843 * *$ & $0.636^{* *}$ & $0.771^{* *}$ & $-0.872 * *$ & $-0.852 * *$ & $0.757 * *$ & -0.134 & $0.900 * *$ \\
\hline
\end{tabular}

**. Correlation is significant at the 0.01 level (2-tailed test). *. Correlation is significant at the 0.05 level(2-tailed test).

(AKP- alkaline phosphates activity, Ur-urease activity, Inv-sucrase activity,BAC-bacteria, FUN-fungi, ACT- actinomycetes)

Table 3. Soil Microbial Characteristics in the natural Leymus chinensis grassland

\begin{tabular}{cccc}
\hline Soil & Bacteria & Fungi & Actinomycetes \\
layers & $\left(\times 10^{4}\right.$ CFU g-1 dry soil $)$ & $\left(\times 10^{2} \mathrm{CFU} \mathrm{g}^{-1} \text { dry soil }\right)^{-1}$ & $\left(\times 10^{4} \mathrm{CFU} \mathrm{g}^{-1}\right.$ dry soil $)$ \\
$(\mathrm{cm})$ & 368 & 172 & 856 \\
\hline $0-5$ & 268 & 42 & 454 \\
$5-10$ & 264 & 46 & 440 \\
$10-20$ & 282 & 16 & 272 \\
$20-30$ & 238 & 42 & 230 \\
$30-40$ & & & \\
\hline
\end{tabular}


Soil microbial characteristics are important indexes for evaluating soil quality (Zhang and Xu, 2008), and soil physicochemical properties were also improved after three years of cultivation in the present study. Further research will be continued in the future.

In the vertical direction, the CFU of bacteria, fungi and actinomycetes all decreased with increased soil depth. This is because the vertical distribution of soil microbes is restricted by the soil physical and chemical characteristics and soil nutrient status. With increased depth, the soil temperature, organic matter and $\mathrm{N}$ all decrease, which is not suitable for growth of most microbes. The roots were mainly distributed in $0-10-\mathrm{cm}$ soil layers, and so soil in this layer has good aeration and rich nutrition - consequently CFU of soil microbes was greater in this layer than in subsoil (Jin et al., 1996).

Our findings suggest that soil microbial characteristics should reach the levels found in natural $L$. chinensis grassland within 6-7 years. The time is much shorter than for the traditional method, which requires more than 10 years to reach levels found in natural grassland (Li and Zheng, 1996). This demonstrated that drip irrigation improves soil microbial characteristics of sodic-saline soil, and provides a theoretical and technological basis for restoring and reconstructing saline-sodic grassland.

\section{Conclusions}

Planting L. chinensis on saline-sodic grassland under drip irrigation had substantial effects on levels of bacteria, fungi and actinomycetes. With increased number of cultivated years under drip irrigation, the soil biological properties were greatly improved. After three years of cultivation, the respective increases in the levels of bacteria, fungi and actinomycetes were 103.7, 72.7 and 58.2 times compared with uncultivated land. In the vertical direction, the CFU of bacteria, fungi and actinomycetes all decreased with increased soil depth. We forecast that the soil microbial characteristics in drip-irrigated saline- sodic soils should match those of natural $L$. chinensis grasslands after 6-7 years of cultivation.

The conclusions of this study were based on only three years of data and the results may have some limitations, and so further research is needed in the following years.

\section{Acknowledgements}

Financial support by the Action Plan for the Development of Western China of the Chinese Academy of Sciences (Grant No. KZCX2-XB2-13), the National Science Foundation for Young Scientists of China (Grant No. 51309175), the scientific research starting project of Taiyuan University of Technology (Grant No. tyut-rc201239a), and the School Foundation of Taiyuan University of Technology (Grant No. 2013T014).

\section{References}

Bååth, E., Frostegård, Å., Pennanen, T., Fritze, H. 1995. Microbial community structure and $\mathrm{pH}$ responses in relation to soil organic matter quality in woodash fertilized, clear-cut or burnt coniferous forest soils. Soil Biology and Biochemistry. 27, 229-240.

Bao, S.D. 2000. Soil agrochemical analysis (in Chinese). In: China Agricultural Press, Beijing, pp 25-114.

Chen, M., Kang, Y.H., Wan, S.Q., Liu, S.P. 2009. Drip irrigation with saline water for oleic sunflower (Helianthus annuus L.). Agricultural Water Management. 96, 1766-1772.

Chi, C.M., Wang, Z.C. 2010. Characterizing saltaffected soils of Songnen Plain using saturated paste and 1:5 soil-to-water extraction methods. Arid Land Research Management. 24(1): 1-11. 
Dick, R.P. 1994. Soil enzyme activities as indicators of soilquality. In: Doran JW, Coleman DC, Bezdicek DF, Stewart BA (eds) Defining soil quality for a sustainable environment. Amrican Society of Agronomy, Madison WI, pp 107-124

Gao, Q., Li, J.D., Zheng, H.Y. 1996. A dynamic landscape simulation model for the alkaline grasslands on Songnen Plain in northeast China. Landscape Ecology. 11, 339-349.

Guan, S.Y. 1986. Soil enzymes and their research methods Agricultural Press, Beijing, pp 273-339.

Hu, W.G., Yan, D., Wang, Z.K., Cheng, M.X., Sun, Y.F. 2007. The preliminary analysis of soil microbial community of planting Achnatherum splendens (Trin) Nevski under saline and alkali land environment. Journal of microbial. 16(1): 197-200.

Jiang, Y.M., Cheng, C.R., Xu, Z.H., Liu, Y.Q. 2012. Effects of single and mixed species forest ecosystems on diversity and function of soil microbial community in subtropical China. Journal of Soils and Sediments. 12, 228-240.

Jin, S.Y., Cui, M.X., Lin, J.S. 1996. Distribution of microorganisms in saline-alkali soil at eastern suburbs of Tianjin and activity of soil enzyme. Chinese Journal of Applied Ecology. 7, 139-141.

Kang, Y.H., Chen, M., Wan, S.Q. 2010. Effects of drip irrigation with saline water on waxy maize (Zea mays L. var. ceratina Kulesh) in North China Plain. Agricultural Water Management. 97, 1303-1309.

Li, J.D., Zheng, H.Y. 1997. Saline-sodic Grassland Management and Bio-ecological Mechanism in the Songnen Plain. Science Press, Beijing.

Li, X.G., Liu, B., C, J.J., Liu, D.D., Ding, S., Gilna, B., Luo, J.Y., Fang, Z.X., Cao, W., Han, Z.M. 2011. No evidence of persistent effects of continuously planted transgenic insect-resistant cotton on soil microorganisms. Plant and Soil. 339, 247-257.
Liu, G.X., Han, J.G. 2008. Seeding establishment of wild and cultivated Leymus chinensis (Trin.) Tzvel. under different seeding depths. Journal of Arid Environments. 72, 279-284.

Liu, S.H., Kang, Y.H., Wan, S.Q., Wang, Z.C., Liang, Z.W., Sun, X.J. 2011. Water and salt regulation and its effects on Leymus chinensis growth under drip irrigation in saline-sodic soils of the Songnen Plain. Agricultural Water Management. 98, 1469-1476.

Oliveira, A., Pampulha, M.E. 2006. Effects of longterm heavy metalcontamination on soil microbial characteristics. Journal of Bioscience and Bioengineering. 102, 157-161.

Papatheodorou, E.M., Argyropoulou, M.D., Stamou, G.P. 2004. The effects of large- and small-scale differences in soil temperature and moisture on bacterial functional diversity and the community of bacterial nematodes. Applied Soil Ecology. 25, 37-49.

Stefanowicz, A. 2006. The Biolog plates technique as a tool in ecological studies of microbial communities. Polish Journal of Environmental Studies. 15, 669-676.

Tan, J.L., Kang, Y.H. 2009. Changes in soil properties under the influences of cropping and drip irrigation during the reclamation of severe saltaffected soils. Agricultural Sciences in China. 8(10): 1228-1237.

U.S. Department of Agriculture (USDA). 1954. Diagnosis and improvement of saline and alkali soils. USDA, Washington, DC.

Wan, S.Q., Kang, Y.H., Wang, D. 2007. Effect of drip irrigation with saline water on tomato (Lycopersicon esculentum Mill) yield and water use in semi-humid area. Agricultural Water Management. 90, 63-74. 
Wang, C.Y., Wu, Z.J., Shi, Y.L., Wang, R.Y. 2004. The Resource of saline soil in the northeast China. Chinese Journal of Soil Sci. 35(5): 643-647.

Wang, L., Seki, K., Miyazaki, T., Ishihama, Y. 2009. The causes of soil alkalinization in the Songnen Plain of Northeast China. Paddy Water Environ. 7, 259-270.

Wang, M.C., Liu, Y.H., Wang, Q., Gong, M., Hua, X.M., Pang, Y.J., Hu, S.J., Yang, Y.H. 2008. Impacts of methamidophos on the biochemical, catabolic, and genetic characteristics of soil microbial communities. Soil Biology and Biochemistry. 40, 778-788.

Wang, P., Li, J.D., Ou, Y.L. 1997. Studies on the adaptability and tolerance of Puccinellia tenuiflora to salinity in the salinized grassland in the Songnen Plain. Acta Agrestia Sinica. 5(2): 80-84.
Xiao, X.M., Wang, Y.F., Jiang, S., Ojima, D.S, Bonham, C.D. 1995. Interannual variation in the climate and above-ground biomass of Leymus chinensis steppe and Stipa grandis steppe in the Xilin river basin, Inner Mongolia, China. Journal of Arid Environment. 31, 283-299.

Yang, L.Y., Xiao, L. 2003. Metagenomics Technology. Science Press, Beijing.

Yu, R.P., Cheng, D.M, 1991. Resources and exploitation of salt-affected soil in China. Chinese Journal of Soil Sci. 30, 158-159.

Zhang, L., Xu, Z.H, 2008. Assessing bacterial diversity in soil. Journal of Soils and Sediments. 8, 379-388. 